\title{
PROTOTIPE SISTEM AUTOBRAKE PADA MOBIL MENGGUNAKAN SENSOR JARAK ULTRASONIK HC-SR04 BERBASIS ARDUINO MEGA 2560
}

\author{
Ari Hidayanto, Heru Winarno \\ Program Studi Diploma III Teknik Elektro \\ Sekolah Vokasi Universitas Diponegoro
}

\begin{abstract}
Ari Hidayanto, Heru Winarno in this paper explain that The high number of traffic accidents is currently a factor in the driver's error in driving (human error). One of the accidents that often occur include car accidents. Of the several incidents that have occurred, the average accident occurred because of the driver's lack of concentration in driving his car. This resulted in the driver not being able to control the speed of the vehicle immediately when there was a sudden object in front, moreover this happened when the vehicle drove at high speed. To avoid this, when driving, it really needs a vehicle security system that also greatly affects the driver's safety. With the development of existing science and technology allows humans to make security systems in motorized vehicles. Accidents due to driver negligence can be overcome by making the braking system automatic then the vehicle speed will slow down and carry out mechanical braking (disc brake) automatically based on the minimum distance of the car with the barrier even though the driver does not pull the brake lever. Realizing this, an autobrake system (automatic braking) was designed based on the distance of the car with the barrier using the HC-SRO4 ultrasonic distance sensor. When between a sensor and a barrier at a distance of $<=70 \mathrm{~cm}$, the central lock actuator will go forward and press the disc brake lever. System notifications will be displayed via 20X4 LCD, LED and Buzzer. The system work will be controlled by Arduino Mega 2560.
\end{abstract}

Keywords: Autobrake, Disc Brake, Ultrasonic sensor HC-SR04, Central Lock, LCD 20x4, Arduino Mega 2560

\section{PENDAHULUAN Latar Belakang}

Tingginya angka kecelakaan lalu lintas saat ini menjadi salah satu faktor kesalahan bagi pengemudi dalam berkendara (human error). Untuk menghindari hal itu, kedisiplinan dan konsentrasi pada saat berkendara sangat dibutuhkan. Namun, kualitas sistem keamanan kendaraan juga sangat mempengaruhi keselamatan pengemudi. Dengan perkembangan ilmu pengetahuan dan teknologi yang telah ada memungkinkan manusia untuk membuat sistem keamanan pada kendaraan. Kecelakaan sering terjadi karena pengendara tidak dapat mengendalikan laju kendaraan dengan segera ketika secara mendadak ada obyek di depan. Terlebih lagi ini terjadi saat kendaraan melaju dengan kecepatan tinggi. Hal ini dapat diatasi dengan membuat sistem pengereman otomatis maka laju kendaraan akan melambat dan melaksanakan pengereman mekanik (disc brake) secara otomatis berdasarkan jarak minimum mobil dengan penghalang meskipun pengendara tidak menarik tuas rem. Sistem keamanan berkendara pada mobil ini merupakan perkembangan dari otomasi otomotif saat inilah yang dimanfaatkan untuk permasalahan di atas. Tujuan yang ingin dicapai dalam penelitian ini adalah merancang prototipe sistem autobrake pada mobil menggunakan sensor ultrasonik HC-SR04 berbasis Arduino Mega 2560 yang menjadi sistem keamanan berkendara pada mobil guna mencegah terjadinya benturan maupun tabrakan.

Batasan Masalah
Dalam penelitian ini ada beberapa batasan masalah yang digunakan, yaitu penggunaan mikrokontroller Arduino Mega 2560 sebagai pusat kendali dalam menjalankan sistem secara keseluruhan, input yang digunakan memakai sensor ultrasonik HC-SR04 dan sensor optocoupler, sedangkan output dari sistem ini berupa central lock, LCD 20X4, LED, Buzzer, dan pembuatan sistem autobrake atau pengereman cakram (disc brake) secara otomatis berdasarkan jarak minimum mobil dengan penghalang.

\section{LANDASAN TEORI \\ Catu Daya}

Catu daya adalah sebuah piranti elektronika yang berguna memberikan sumber daya untuk piranti lain sehingga piranti lain tersebut mampu untuk bekerja, terutama daya listrik. Sel-sel listrik dan baterai cukup ideal untuk memberikan tenaga bagi perangkat-perangkat portable semisal senter dan kalkulator. Perangkat-perangkat lain yang bekerja dengan tegangan rendah mengambil energi dari sumber listrik PLN, dengan menggunakan unit catu daya (Power Supply Unit atau PSU) bertegangan rendah.

\section{Accumulator (Aki)}

Accumulator atau sering disebut aki, adalah salah satu komponen utama dalam kendaraan bermotor, baik mobil atau motor, semua memerlukan aki untuk dapat menghidupkan mesin mobil (mencatu arus pada dinamo stater kendaraan). Aki mampu mengubah tenaga kimia menjadi tenaga listrik. Tentu saja aki ini dapat dimuati kembali (recharge) apabila muatannya telah berkurang atau habis. Pada alat 
autobrake ini memakai catu daya DC dari 2 aki basah $12 \mathrm{~V} / 10 \mathrm{AH}$ yang diseri sehingga mendapatkan tegangan sebesar 24 VDC. Dimana aki basah memiliki ciri khusus yaitu wadahnya yang ttransparan sehingga terlihat sel-sel penyusun dengan cairan elektrolitnya

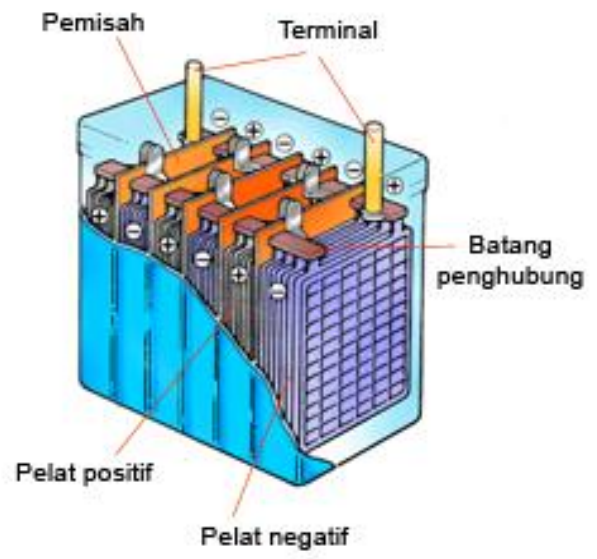

Gambar 1. Struktur Aki Basah

Kapasitas accu dinyatakan dalam Ampere/Hour (AH). Secara teoritis, ini berarti arus yang mengalir di dalam hitungan jam. Sebagai contoh sebuah accu motor tertulis $4 \mathrm{AH}$ (Ampere Hours), maka ini artinya accu tersebut mampu mengalirkan arus sebesar empat Ampere selama satu jam hingga isinya habis dan mencapai titik nol. Jika accu mengalirkan arus hanya satu Ampere maka ia mampu bertahan selama empat jam hingga isinya habis dan mencapai titik nol.

\section{Voltage Regulator (Pengatur Tegangan)}

Pengatur tegangan (voltage regulator) berfungsi menyediakan suatu tegangan keluaran DC tetap yang tidak dipengaruhi oleh perubahan tegangan masukan, arus beban keluaran, dan suhu. Pengatur tegangan adalah salah satu bagian dari rangkaian catu daya DC. Regulator berfungsi untuk mengatur kestabilan arus yang mengalir ke rangkaian elektronika. Pada dasarnya IC regulator merupakan rangkaian elektronik dengan komponen utama dioda zener sebagai pembatas tegangan. Dioda zener memiliki prinsip kerja meregulasi tegangan input atau mengalirkan arus listrik secara berlawanan jika tegangan melampaui batas tegangan pada dioda zener. Apabila tegangan input dioda zener sama dengan atau kurang dari tegangan tetapan dioda zener maka tegangan hanya akan diteruskan atau tegangan output akan bernilai tetap.

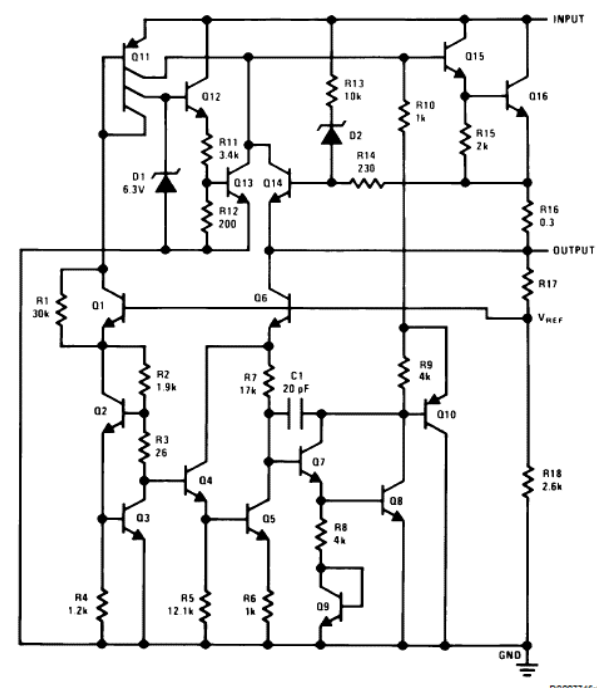

Gambar 2. Rangkaian Terpadu Pada IC Regulator LM78XX

\section{Sensor Ultrasonik HC-SR04}

Sensor ultrasonik adalah sensor yang bekerja berdasarkan prinsip pantulan gelombang suara dan digunakan untuk mendeteksi keberadaan suatu objek tertentu di depannya, frekuensi kerjanya pada daerah di atas gelombang suara dari $40 \mathrm{KHz}$ hingga 400 $\mathrm{KHz}$.

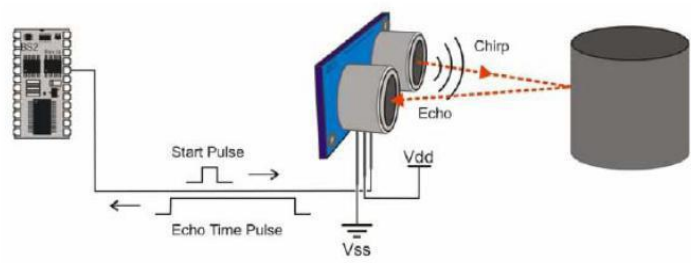

Gambar 3. Prinsip Kerja Sensor Ultrasonik

Sensor jarak ultrasonic ranging module HC-SR04 dapat mendeteksi pengukuran jarak non-kontak dari $2 \mathrm{~cm}-400 \mathrm{~cm}$, akurasi jangkauan sekitar $3 \mathrm{~mm}$. Module terdiri dari ultrasonik transmitter dan receiver serta rangkaian kontrol. Sensor ultrasonik HC-SR04 memiliki 4 pin yaitu VCC, Trigger, Echo, dan GND dengan begitu kelebihan sensor ultrasonik HC-SR04 adalah pantulan gelombang suara pada saaat proses kerja terjadi sangat cepat bahkan hampir tidak ada delay, karena pulsa trigger (pemicu) dan pulsa echo (penerima) diakses dengan port yang berbeda.

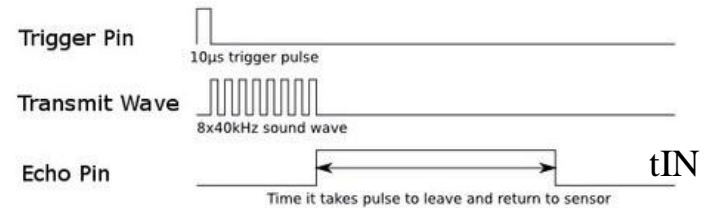

Gambar 4. Timing Diagram HC-SR04

$\mathrm{S}=\mathrm{V} \times \mathrm{t}_{\text {in }} / 2$

Keterangan:

S : Jarak sensor terhadap objek

V : Kecepatan suara di udara $(344 \mathrm{~m} / \mathrm{s})$ 
$t_{\text {in }}$ : Jumlah waktu tempuh pemantulan dan penerimaan gelombang

\section{Optopcoupler Sebagai Sensor Kecepatan}

Optocoupler adalah suatu piranti yang terdiri dari 2 bagian yaitu transmitter dan receiver, yaitu antara bagian cahaya dengan bagian deteksi sumber cahaya terpisah. Biasanya optocoupler digunakan sebagai saklar elektrik, yang bekerja secara otomatis. Optocoupler atau optoisolator merupakan komponen penggandeng (coupling) antara rangkaian input dengan rangkaian output yang menggunakan media cahaya (opto) sebagai penghubung. Dengan kata lain, tidak ada bagian yang konduktif antara kedua rangkaian tersebut. . Sensor putaran atau kecepatan ini dibuat dengan optocoupler tipe " $U$ " yang ditengahnya diletakan sebuah roda cacah. Optocoupler merupakan komponen optoisolator yang memiliki karakteristik penerima (photo transistor) akan mengalami perubahan logika bila terjadi perubahan intensitas cahaya yang dipancarkan oleh pemancar (LED infra merah) untuk penerima.

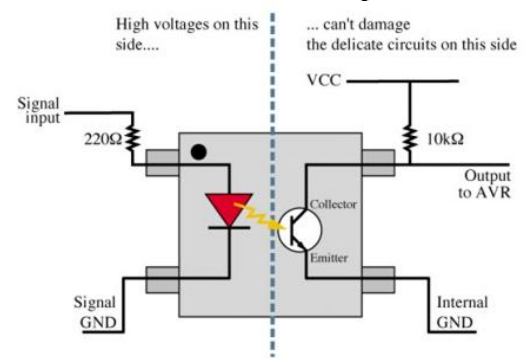

Gambar 5. Rangkaian Optocoupler

1. Jika antara phototransistor dan LED terhalang maka phototransistor tersebut akan off sehingga output dari kolektor akan berlogika high.

2. Sebaliknya jika antara phototransistor dan LED tidak terhalang maka maka phototransistor tersebut akan on sehingga outputnya akan berlogika low.

Rumus pemrograman untuk mengkonversi antara outputan optocoupler pada Arduino sehingga hasilnya dapat ditampilkan dalam LCD berupa RPM adalah sebagai berikut:

rpmnya $=($ float $)$ rpmcount $* 60.0 / 36.0$

\section{LCD 20x4}

LCD (Liquid Cristal Display) adalah salah satu jenis display elektronik yang dibuat dengan teknologi CMOS logic yang bekerja dengan tidak menghasilkan cahaya tetapi memantulkan cahaya yang ada di sekelilingnya terhadap front-lit atau mentransmisikan cahaya dari back-lit. LCD berfungsi sebagai penampil data baik dalam bentuk karakter, huruf, angka ataupun grafik. LCD ini mempunyai delapan jalur data (DB0 s/d DB7) dan tiga jalur control (RS, R/W, E). Modul ini menggunakan tegangan Vcc sebesar $+5 \mathrm{~V}$.

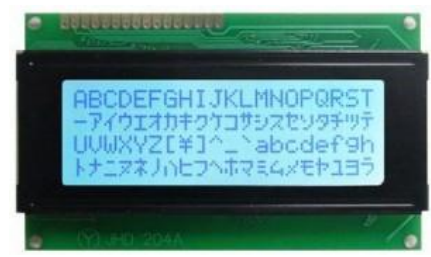

Gambar 6. LCD 20x4

\section{LED (Light Emitting Dioda)}

LED adalah singkatan dari Light Emitting Dioda, merupakan produk temuan lain setelah dioda yang dapat memancarkan cahaya bila dibias maju. Gejala ini termasuk bentuk electroluminescence. Seperti sebuah dioda normal, dia terdiri dari sebuah chip bahan semikonduktor yang di-dop dengan ketidakmurnian untuk menciptakan sebuah struktur yang disebut p-n junction. Pembawa muatan elektron dan lubang mengalir ke junction dari elektroda dengan voltase berbeda. Ketika elektron bertemu dengan lubang, dia jatuh ke tingkat energi yang lebih rendah, dan melepaskan energi dalam bentuk foton. Perhatikan gambar berikut.

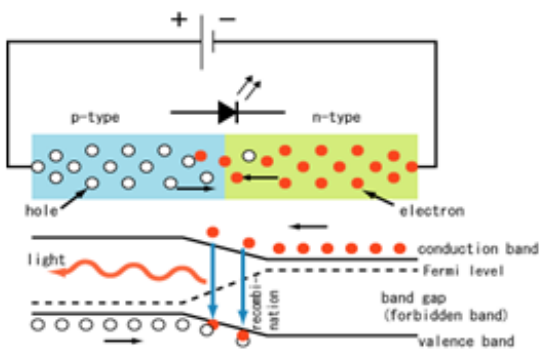

Gambar 7. Simbol dan Karakteristik LED

Intensitas cahaya yang dipancarkan tergantung pada banyaknya pembawa minoritas yang tersedia untuk rekombinasi atau arus yang mengalir.

\section{Buzzer}

Buzzer adalah sebuah komponen elektronika yang berfungsi untuk mengubah getaran listrik menjadi getaran suara. Buzzer adalah sebuah komponen elektronika yang berfungsi untuk mengubah getaran listrik menjadi getaran suara. Suara yang dihasilkan tergolong sederhana yakni monofonik, beda dengan speaker yang dapat mengeluarkan suara yang lebih variatif (polifonik).

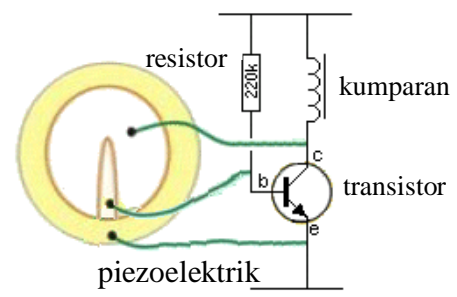

Gambar 8. Rangkaian Buzzer

Pada dasarnya prinsip kerja buzzer hampir sama dengan loud speaker, jadi buzzer juga terdiri dari kumparan dan rangkaian piezoelektrik, kemudian kumparan tersebut dialiri arus sehingga menjadi elektromagnet, kumparan tadi akan tertarik ke dalam 
atau keluar, tergantung dari arah arus dan polaritas magnetnya, karena kumparan dipasang pada piezoelektrik maka setiap gerakan kumparan akan menggerakkan piezoelektrik secara bolak-balik sehingga membuat udara bergetar yang akan menghasilkan suara.

\section{Driver Motor L298N}

Driver motor L298N merupakan driver motor yang cukup populer digunakan dalam pengaturan kecepatan dan arah putar motor DC. Kelebihan dari driver motor L298N ini adalah cukup presisi dalam mengontrol motor. Selain itu, kelebihan driver motor L298N adalah mudah untuk dikontrol. Untuk mengontrol driver L298N ini dibutuhkan 6 buah pin mikrokontroler. Dua buah untuk pin Enable ( satu buah untuk motor pertama dan satu buah yang lain untuk motor kedua, karena driver L298N ini dapat mengontrol dua buah motor DC), 4 buah untuk mengatur kecepatan motor-motor tersebut. Prinsip kerja pengaturan arah putaran motor dari driver motor 298N menggunakan prinsip H-bridge, sedangkan pengaturan kecepatan putaran motor menggunakan PWM.

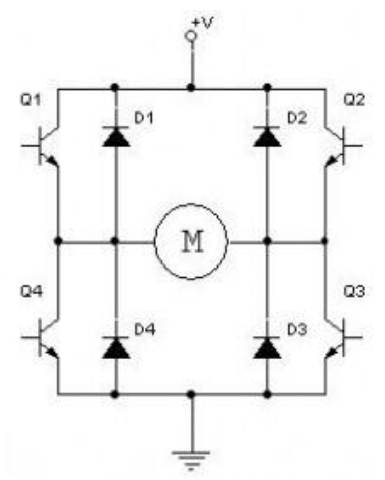

Gambar 9. Prinsip Pergerakan Rangkaian Driver Motor

\section{Central Door Lock}

Pada hakekatnya, central lock adalah mekanisme pengendalian kunci seluruh pintu mobil dengan sebuah kontrol terpusat. Dengan teknologi ini, pemilik mobil dapat mengendalikan seluruh kunci pintu hanya dengan satu langkah sederhana. Motor Central Door Lock pada door lock, aktuator menggunakan motor DC sebagai penggeraknya. Kelebihan motor DC adalah dapat diubah arah putarannya dengan mengubah arah arus listriknya. Sedangkan motor Central Door Lock berfungsi sebagai actuator untuk menggerakkan tuas pengunci pada pintu mobil untuk posisi Lock gerakan motor turun dan posisi Unlock gerakan motor naik. Pada mekanisme aktuator (lebih lanjut), yang paling umum digunakan adalah sistem geared motor DC yang dimanipulasi secara mekanika hingga memberikan gerakan longitudinal (geser). Dengan mekanisme tersebut, motor DC hanya memerlukan listrik dengan variasi polaritas (-+/+-) untuk menarik dan mendorong ujung aktuator.

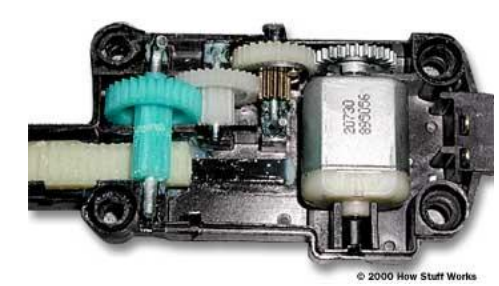

Gambar 10. Susunan Gearbox Central Lock Arduino Mega 2560

Arduino Mega 2560 adalah papan kit elektronik atau papan rangkaian elektronik open source yang di dalamnya terdapat komponen utama yaitu sebuah chip mikrokontroler Atmega2560 dengan jenis AVR dari perusahaan Atmel. Mikrokontroler itu sendiri adalah chip atau IC (integrated circuit) yang bisa diprogram menggunakan komputer. Tujuan menanamkan program pada mikrokontroler adalah agar rangkaian elektronik dapat membaca input, memproses input tersebut dan kemudian menghasilkan output sesuai yang diinginkan. Jadi mikrokontroler bertugas sebagai 'otak' yang mengendalikan input, proses dan output sebuah rangkaian elektronik. Arduino Mega 2560 merupakan mikrokontroler ATmega2560 yang memiliki tegangan kerja sebesar 5 VDC, 54 digital input/output (15 diantaranya digunakan sebagai output PWM), input analog 16, 4 UART (port serial hardware), osilator kristal $16 \mathrm{MHz}$, koneksi USB, jack listrik, header ICSP, dan tombol reset.

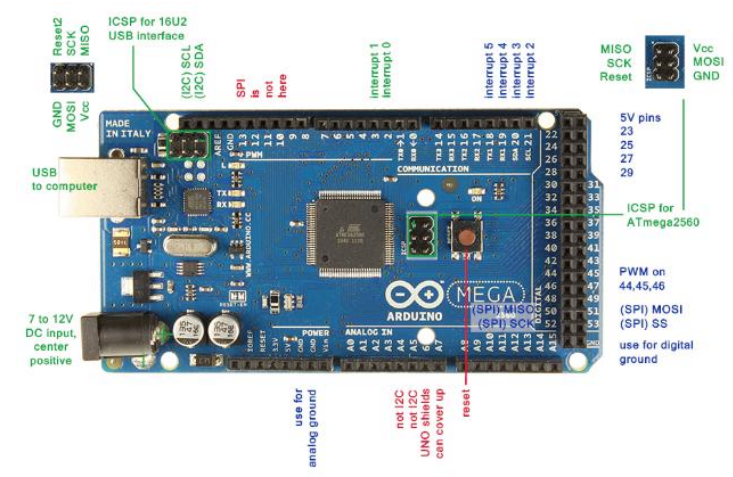

Gambar 11. Arduino Mega 2560

\section{PWM (Pulse Width Modulation)}

Pulse Width Modulation (PWM) secara umum adalah sebuah cara memanipulasi lebar sinyal yaitu duty cycle yang dinyatakan dengan pulsa dalam suatu perioda, untuk mendapatkan tegangan rata-rata yang berbeda. Beberapa Contoh aplikasi PWM adalah pemodulasian data untuk telekomunikasi, pengontrolan daya atau tegangan yang masuk ke beban, regulator tegangan, audio effect dan penguatan, serta aplikasi-aplikasi lainnya. Aplikasi PWM berbasis mikrokontroler biasanya berupa, pengendalian kecepatan motor DC, Pengendalian Motor Servo, Pengaturan nyala terang LED. 


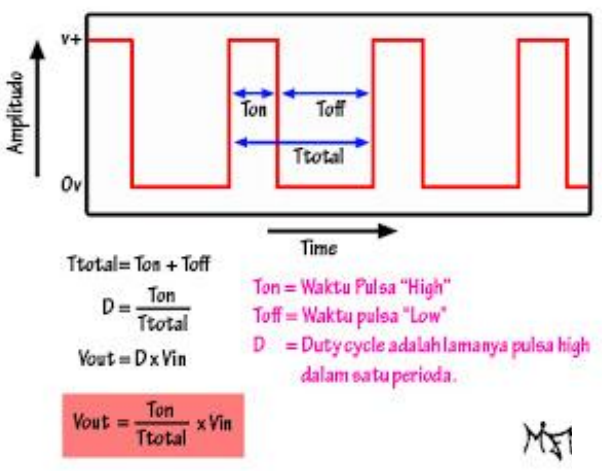

Gambar Sinyal 12. PWM dan Persamaan Vout PWM

Dari persamaan diatas diketahui bahwa perubahan duty cycle akan merubah tegangan keluaran atau tegangan rata-rata seperti gambar di bawah ini.
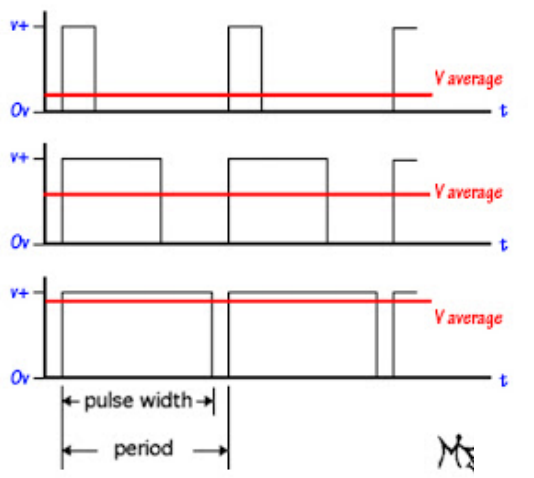

Gambar 13. V $V_{\text {rata-rata }}$ Sinyal PWM

\section{Pengereman Mobil}

Rem merupakan salah satu komponen mesin mekanik yang sangat vital keberadaannya. Adanya rem memberikan gaya gesek pada suatu massa yang bergerak sehingga berkurang kecepatannya atau berhenti. Pemakaian rem banyak ditemui pada sistem mekanik yang kecepatan geraknya berubah-ubah seperti pada roda kendaraan bermotor, poros berputar, dan sebagainya. Berarti dapat disimpulkan bahwa fungsi utama rem adalah untuk menghentikan putaran poros, mengatur putaran poros, dan juga mencegah putaran yang tidak dikehendaki. Sistem pengereman pada mobil menggunakan rem kaki. Rem kaki (foot brake) dikelompokkan menjadi dua tipe : rem hidraulis (hydraulic brake) dan rem pneumatis (pneumatis brake). Rem hidraulis mempunyai keuntungan lebih respon (lebih cepat) dan konstruksi lebih sederhana, sedangkan rem pneumatis menggunakan kompresor yang menghasilkan udara bertekanan untuk menambah daya pengereman.

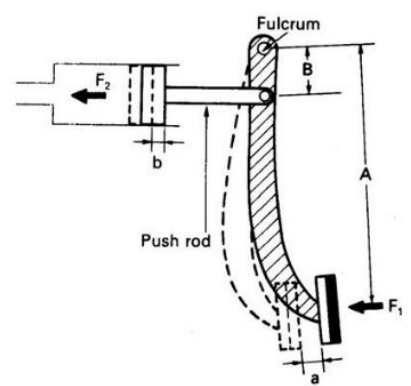

Gambar 14. Perhitungan Gaya Tekan Rem Hidraulis

$$
\mathrm{F}_{2}=\mathrm{F}_{1} \times \mathrm{A} / \mathrm{B}
$$

$\mathrm{F}_{1}$ : Tenaga pedal $(\mathrm{kg})$

$\mathrm{A}_{1}$ : Jarak pedal ke fulcrum

$\mathrm{F}_{2}$ : Output push rod $(\mathrm{kg})$

$\mathrm{A}_{2}$ : Jarak pushrod ke fulcrum

\section{PERANCANGAN SISTEM}

Pada Sistem Autobrake Pada Mobil Menggunakan Sensor Jarak Ultrasonik HC-SR04 Berbasis Arduino Mega 2560 dibuat untuk memberikan sistem keamanan dan kenyamanan dalam mengendarai mobil. Pada simulasi yang telah dibuat, alat akan menyala jika tombol START ditekan, maka tegangan sebesar 24 VDC/10 AH (dari 2 aki yang diseri) unutk supply motor DC akan diregulasi oleh regulator tegangan sebesar 12 VDC sebagai inputan Arduino Mega 2560. Dengan begitu motor DC sebagai simulasi perputaran roda, sensor jarak ultrasonik HC-SR04, sensor keceptan, dan LCD sebagai display hasil pengolahan input sensor ultrasonik dan sensor kecepatan. Pada tahap ini sistem autobrake belum aktif, jika ingin mengaktifkan maka harus menekan tombol ON. Sistem autobrake (aktuator central lock), indikator LED, dan buzzer akan aktif jika jarak yang terdeteksi oleh sensor jarak ultraasonik HC-SR04 $<=70 \mathrm{~cm}$ atau sesuai instrulsi program yang telah diupload pada Arduino Mega 2560. Jika jarak yang terdeteksi , s= $70 \mathrm{~cm}$ maka Arduino Mega akan Menginstruksikan kepada driver motor L298N untuk menggerakkan secara forward aktuator central lock melalui IN1: 1 dan IN2: 0. Input tegangan sistem adalah $24 \mathrm{VDC}$, sedangkan aktuator central yang hanya mampu menerima tegangan input sebesar 12 VDC maka diaturlah tegangan input unutk aktuator central lock dengan metode PWM sebesar $50 \%$ (12 VDC) melalui port ENA pada motor driver L298N. Aktuator central lock yang bergerak maju akan menekan tuas rem sehingga pengereman mekanik akan aktif. Kecepatan dimonitoring oleh sensor kecepatan bahwa roda benar-benar berhenti atau kecepatannya 0 RPM. Indikator nyalanya sistem autobrake akan ditampilkan oleh nyalanya LED dan buzzer secara kontinyu selama sistem autobrake aktif dan muncul tampilan "Autobrake" di baris ketiga LCD. Apabila jarak yang dideteksi oleh sensor ultrasonik HC-SR04 > $70 \mathrm{~cm}$ maka aktuator central lock tidak bertegangan sehingga tuas rem tidak ada penekanan dan rem tidask aktif. LED dan buzzer 
indikator autobrake akan mati dan tulisan "Autobrake" juga menghilang. Jika ingin mematikan sistem tekan kembali tombol OFF yang sebelumnya ON. Jika ingin mematikan kerja alat tekan kembali tombol STOP yang sebelumnya START.

\section{Blok Diagram}

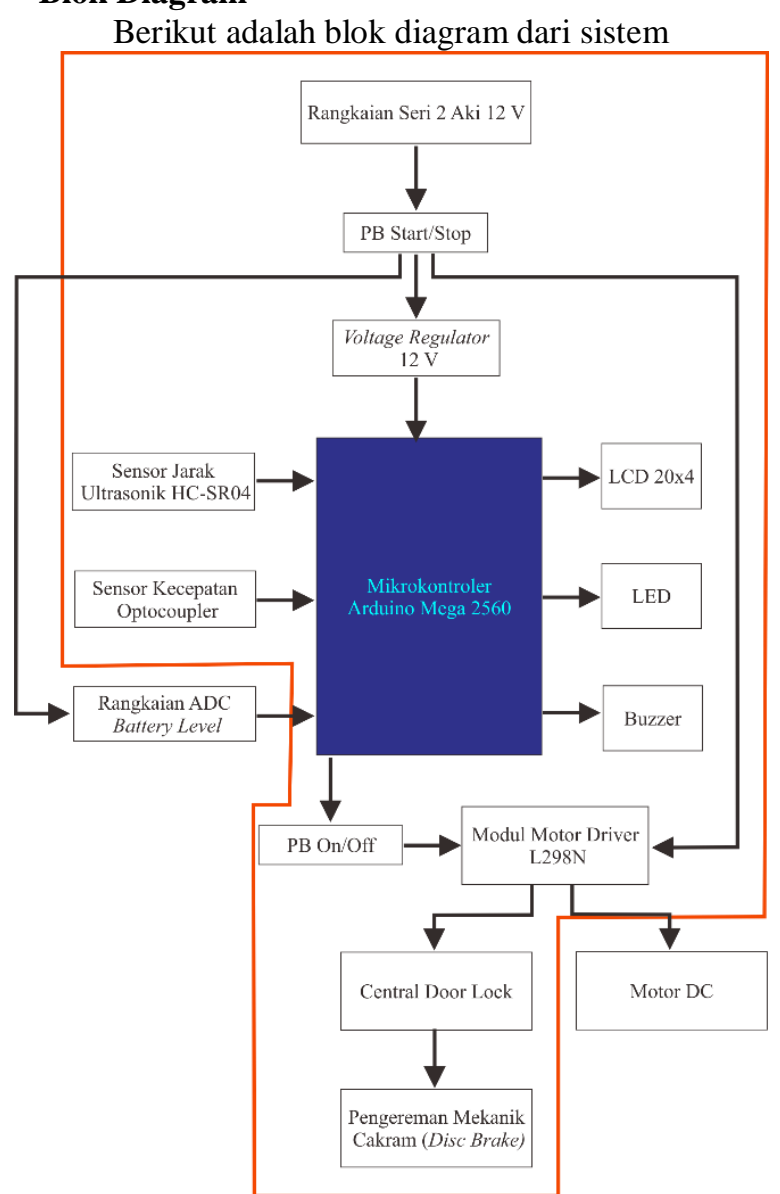

Gambar 15. Blok Diagram Sistem

\section{Flowchart Sistem}

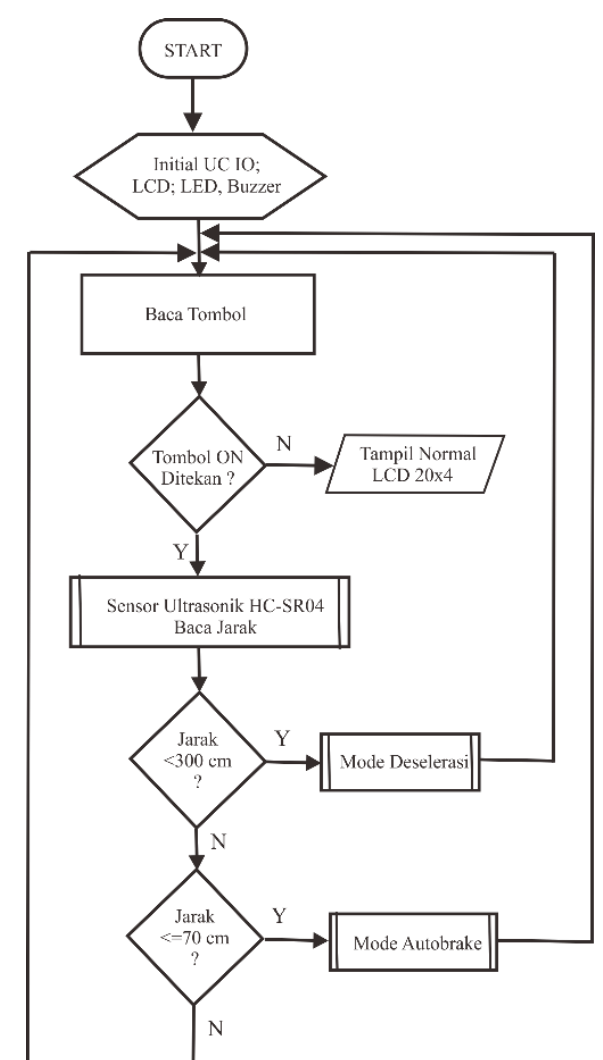

Gambar 16. Flowchart Sistem Keseluruhan

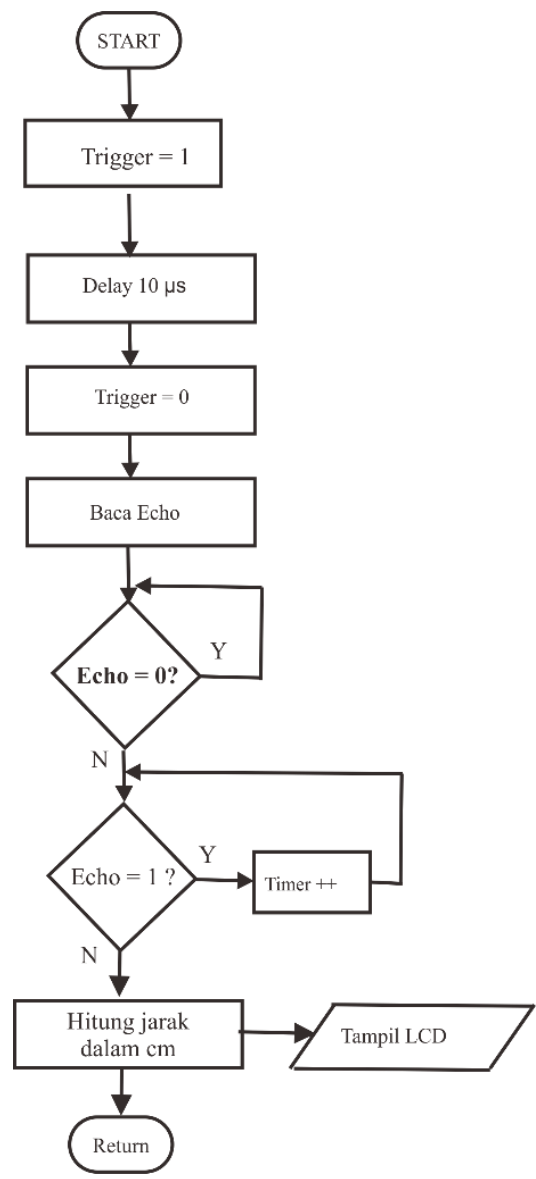

Gambar17. Flowchart Sensor Ultrasonik HC-SR04 


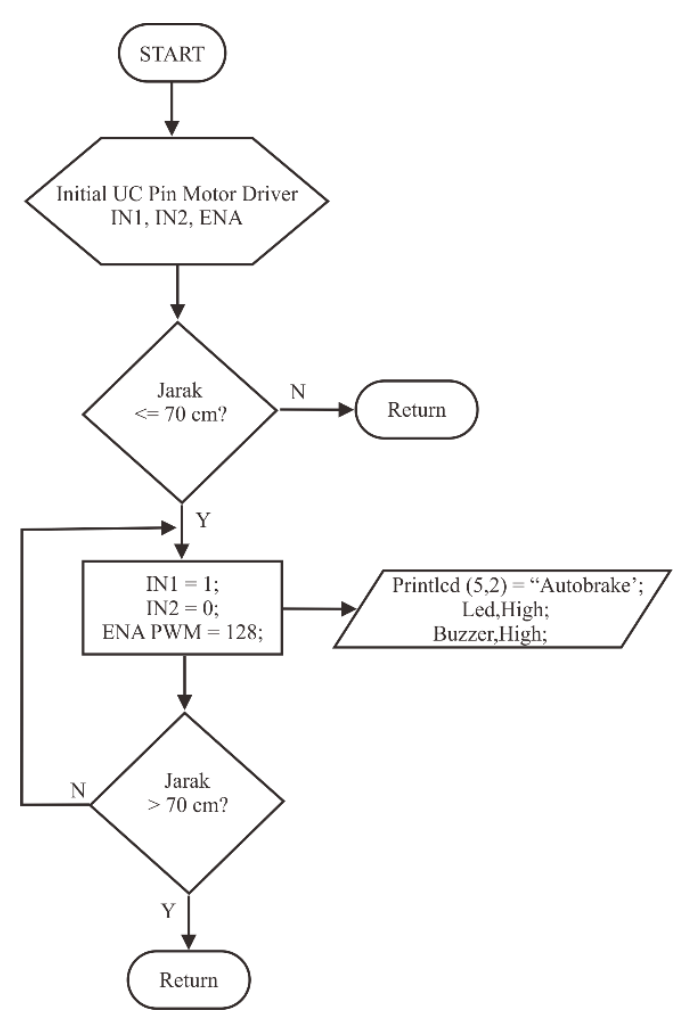

Gambar 18. Flowchart Sistem Autobrake

\section{PEMBUATAN SISTEM}

Pada dasarnya dalam mengimplementasikan pembuatan sistem ini dibagi menjadi 2 bagian yaitu :

- Pemasangan perangkat keras (hardware)

Tahap pertama ini meliputi semua proses pemasangan perangkat keras untuk merealisasikan rancangan yang telah dibuat menjadi sistem yang siap untuk dioperasikan.

- Pembuatan software

Tahap kedua ini yaitu mencakup semua hal yang berkaitan dengan perangkat lunak bagi sistem.

Masing-masing bagian mempunyai tujuan yang sama yaitu agar kedua bagian yang merupakan satu kesatuan sistem yang akan dibuat dapat saling melengkapi satu sama lain sehingga tercipta suatu sistem yang baik. Langkah awal pembuatan tugas akhir ini adalah perencanaan dan konsep yang jelas tentang aplikasi yang akan dibuat. Agar kendalakendala yang tidak diinginkan pada proses pembuatan dapat diperhitungkan dan diselesaikan.

Dalam proses pembuatan aplikasi ini pembuatan hardware dan software sama-sama ditekankan karena pokok pembahasan dalam tugas akhir ini tentunya mengacu pada realisasi mekanik yang selaras dengan Arduino Mega 2560.

\section{Pemasangan Perangkat Keras}

Pemasangan perangkat keras ini bertujuan untuk menunjang software dalam Arduino Mega 2560. Tampilan alat keseluruhan dari rangkaian perangkat keras yang dibuat berupa layaknya potongan bagian depan sebelah kanan mobil seperti gambar berikut.

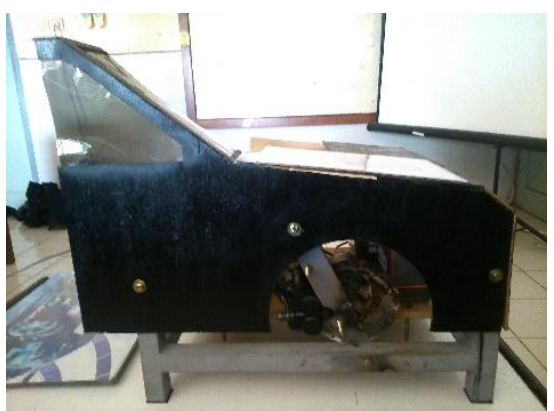

Gambar 19. Alat Jadi Tampak Samping Kanan

Sedangkan perangkat keras yang digunakan beserta fungsinya adalah sebagai berikut.

Tabel 1. Perangkat Keras

\begin{tabular}{|c|c|c|}
\hline Alat & Jumlah & Fungsi \\
\hline $\begin{array}{c}\text { Sensor } \\
\text { Ultrasonik HC- } \\
\text { SR04 }\end{array}$ & 2 buah & $\begin{array}{lr}\text { Pendeteksi } & \text { jarak } \\
\text { antara } & \text { bagian } \\
\text { depan } & \text { mobil } \\
\text { dengan penghalang } \\
\text { di depannya. }\end{array}$ \\
\hline $\begin{array}{c}\text { Sensor } \\
\text { Kecepatan }\end{array}$ & 1 buah & $\begin{array}{l}\text { Pemonitoring dari } \\
\text { kecepatan putat } \\
\text { dari motor DC } \\
\text { sebagai simulasi } \\
\text { roda mobil. }\end{array}$ \\
\hline $\begin{array}{c}\text { Arduino Mega } \\
2560\end{array}$ & 1 buah & $\begin{array}{l}\text { Pusat kendali kerja } \\
\text { sistem }\end{array}$ \\
\hline $\begin{array}{l}\text { Motor Driver } \\
\text { L29N }\end{array}$ & 1 buah & $\begin{array}{l}\text { Perangkat pengatur } \\
\text { kecepatan dan arah } \\
\text { putar motor DC }\end{array}$ \\
\hline $\begin{array}{c}\text { Aktuator } \\
\text { Central Lock }\end{array}$ & 1 buah & Penekan tuas rem \\
\hline LCD 20X4 & 1 buah & $\begin{array}{l}\text { Output tampilan } \\
\text { hasil pengolahan } \\
\text { dari input }\end{array}$ \\
\hline $\begin{array}{l}\text { LED dan } \\
\text { Buzzer }\end{array}$ & $\begin{array}{l}3 \text { buah } \\
\text { dan } 1 \\
\text { buah }\end{array}$ & $\begin{array}{l}\text { Indikator } \\
\text { aktif }\end{array}$ \\
\hline
\end{tabular}

\section{Pembuatan Software}

Dalam pembuatan tugas akhir ini pembuatan perangkat lunak sangatlah penting. Perangkat lunak yang dimaksud adalah perangkat lunak atau program pada modul Arduino Mega 2560. Langkahlangkahnya sebagai berikut:

1. Membuat diagram alir (flowchart) dari program yang dibuat.

2. Membuat program menggunakan pemrograman berbahasa $\mathrm{C}$ arduino IDE yang dengan referensi diagram alir.

3. Mengkompilasi program yang telah dibuat sampai tidak terjadi kesalahan.

4. Pengisian (upload) program.

\section{PENGUKURAN DAN PENGUJIAN}

Pengujian pengukuran dan pengujian benda kerja berguna untuk mendapatkan data-data spesifik pada titik-titik pengukuran dari alat yang telah dibuat, sehingga mempermudah menganalisa sistem dan 
memperbaiki kerusakan yang mungkin terjadi pada saat alat ini bekerja.

Dalam pengukuran dan pengujian ini dilakukan dengan menggunakan peralatan antara lain:

- Multimeter

- Tachometer

- Meteran / Penggaris

\section{Pengukuran}

Pengukuran dilakukan pada masing-masing rangkaian untuk mengetahui kemungkinan adanya kesalahan pada rangkaian dan besar tegangan keluarannya menggunakan multimeter. Adapun rangkaian yang diukur dan dicoba pada pembuatan sistem ini yaitu rangkaian catu daya, Arduino Mega 2560, rangkaian sensor ultrasonic HC-SR04, rangkaian sensor optocoupler, driver motor L298N, rangkaian central lock, rangkaian display LCD 20x4, rangkaian LED dan buzzer. Berikut adalah salah satu contoh mode pengukuran yang dilakukan, yaitu menukur tegangan pada pin-pin sensor jarak ultrasonik HC-SR04 yang merupakan sebuah inputan terintegrasi dengan Arduino Mega 2560 sebagai otak dalam kerja sistem dan pemrosesan hasilnya.

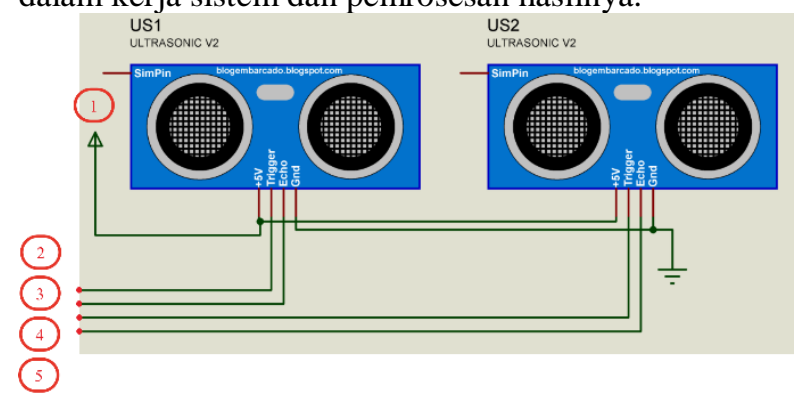

Gambar 20. Titik Pengukuran Tegangan Sensor Ultrasonik HC-SR04 Tabel 2.

Data hasil pengukurannya ditunjukkan pada

Tabel 2. Pengukuran Tegangan Sensor Ultrasonik HC-SR04

\begin{tabular}{lcccc}
\hline No. & Pengukuran & $\begin{array}{c}\text { Titik } \\
\text { Pengukuran }\end{array}$ & H/L & $\begin{array}{c}\text { Tegangan } \\
\text { (V) }\end{array}$ \\
\hline 1. & VCC & 1 dengan GND & - & 4,87 \\
2. & \multirow{2}{*}{ Trigger } & 2 dengan GND & - & 4,86 \\
& & 4 dengan GND & - & 4,86 \\
& \multirow{2}{*}{ 3 dengan GND } & H & 2,3 \\
3. & Echo & & $\mathrm{L}$ & 0,36 \\
& & 5 dengan GND & $\mathrm{H}$ & 2,3 \\
& & $\mathrm{~L}$ & 0,36 \\
\hline
\end{tabular}

\section{Pengujian}

Pada alat pengereman otomatis pada mobil atau Sistem Autobrake Pada Mobil Menggunakan Sensor Jarak Ultrasonik HC-SR04 Berbasis Arduino Mega 2560 ini, pengujian dilakukan dengan membandingkan hasil pengukuran jarak sensor ultrasonik HC-SR04 dengan meteran / penggaris, sensor kecepatan dengan tachometer, dan pengujian aktuator central lock sebagai penekan tuas rem. Pengujian aktuator yang merupakan output mekanik dari pengukuran sensor ultrasonik HC-SR04 akan dibandingkan berdasarkan cara penghalangan sensor, yaitu dengan penghalangan secara halus (dengan deselerasi) dan penghalangan mendadak. Gambaran dari pengujian tersebut dapat dilihat pada gambar berikut.

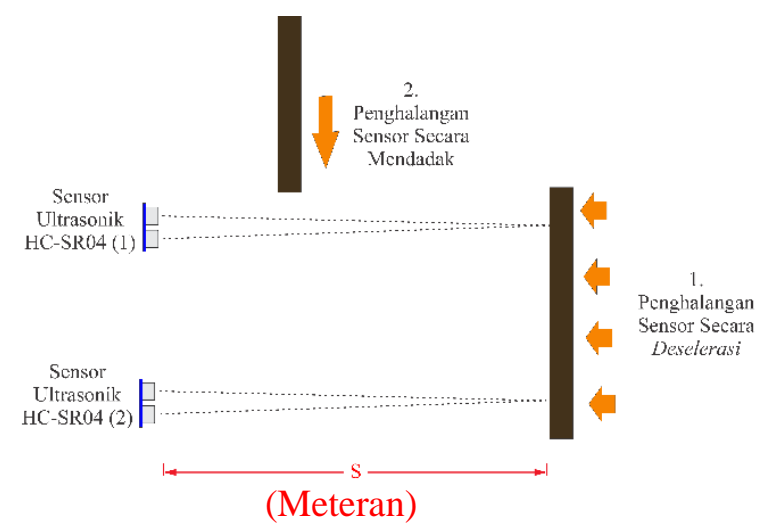

Gambar 21 Skema Pengujian Sensor Ultrasonik HCSR04 Untuk Central Lock Tabel 3 .

Hasil pengujian central lock dapat dilihat pada

Tabel 3. Pengujian Aktuator Central Lock

\begin{tabular}{ccc}
\hline No. $\begin{array}{c}\text { Metode } \\
\text { Penghalangan }\end{array}$ & $\begin{array}{c}\text { Range Jarak } \\
\text { Sensor } \\
\text { Ultrasonik HC- } \\
\text { SR04 dengan } \\
\text { Penghalang }\end{array}$ & $\begin{array}{c}\text { Kondisi } \\
\text { Aktuator } \\
\text { Central } \\
\text { Lock }\end{array}$ \\
\hline & $240 \mathrm{~cm}-190 \mathrm{~cm}$ & 0 \\
& $190 \mathrm{~cm}-150 \mathrm{~cm}$ & 0 \\
1. $\quad \begin{array}{c}\text { Dengan } \\
\text { Deselerasi }\end{array}$ & $150 \mathrm{~cm}-110 \mathrm{~cm}$ & 1 \\
& $110 \mathrm{~cm}-70 \mathrm{~cm}$ & $0-1$ \\
& $<=70 \mathrm{~cm}$ & 1 \\
& $190 \mathrm{~cm}$ & 0 \\
& $150 \mathrm{~cm}$ & 0 \\
& $110 \mathrm{~cm}$ & 0 \\
2. & $70 \mathrm{~cm}$ & 1 \\
& $<=70 \mathrm{~cm}$ & 1 \\
\hline
\end{tabular}

Keterangan: $0=$ Tidak aktif, $1=$ Aktif

Dari tabel 3 dapat diketahui bahwa aktuator central lock akan aktif jika jarak $<=70 \mathrm{~cm}$ sesuai dengan program yang telah diupload pada Arduino Mega 2560. 


\section{KESIMPULAN}

Dalam penelitian yang berjudul "Sistem Autobrake Pada Moobil Menggunakan Sensor Jarak Ultrasonik HC-SR04 Berbasis Arduino Mega 2560" penulis mengambil beberapa kesimpulan yang didapat selama proses perancangan alat yaitu:

- Modul Arduino Mega 2650 sebagai otak pemrosesan semua input yang terdiri dari data pembacaan jarak dan kecepatan, output berupa tampilan dalam display LCD 20x4, buzzer dan LED sebagai indikator sistem autobrake aktif, dan mengaktifkan aktuator central lock untuk sistem autobrake jika pembacaan jarak sensorultrasonik $<=70 \mathrm{~cm}$.

- Penggunaan sensor jarak ultrasonik HC-SR04 pada sistem autobrake memiliki tingkat eror valid rata-rata sebesar $0,33 \%$ dengan range jarak yang telah ditetapkan oleh program sebesar $300 \mathrm{~cm}$.

- Sensor kecepatan optocoupler pada sistem autobrake digunakan untuk memberikan informasi kecepatan putaran motor DC (sebagai roda) dan kondisinya telah benar-benar berhenti. Dari hasil pengujian sensor optocoupler tersebut memiliki tingkat error di bawah $1 \%$.

- Aktuator central lock yang mendapatkan tegangan optimum sebesar $12 \mathrm{~V}-15 \mathrm{~V}$ dan akan menjadikan mesin motor central lock panas jika tegangannya lebih dari $15 \mathrm{~V}$.

- Driver motor DC L298N mampu menerima tegangan hingga $46 \mathrm{~V}$ dan arus hingga $4 \mathrm{~A}$ serta mampu mengontrol kecepatan maupun arah putaran 2 motor DC secara bersamaan ataupun sendiri-sendiri.

- LED, buzzer, dan LCD 20x4 sebagai media informasi hasil pengolahan Arduino Mega 2560 yang mendapatkan tegangan yang rendah antara $2 \mathrm{~V}-5 \mathrm{~V}$.

- $\quad$ Sistem autobrake ini berbeda dengan ABS (Antilock Brake System), dimana autobrake aktif pada jarak minimum moncong mobil dengan penghalang, sedangkan ABS dibuat untuk menghindari locking (penguncian) penuh dari rem.

Penulis menyadari bahwa masih banyak yang dapat dikembangkan dari alat ini baik oleh penyusun. Menurut penulis, beberapa hal yang dapat digunakan sebagai bahan pertimbangan untuk pengembangan sistem selanjutnya adalah sebagai berikut:

- Untuk aplikasi sensor jarak ultrasonik lebih baik menggunakan sensor yang memiliki spesifikasi yang lebih baik lagi, seperti sensor jarak ultrasonik URM06 yang memiliki jarak ukur hingga $10 \mathrm{~m}$ berdasarkan datasheetnya dengan harga yang hampir 22 kali harga sensor jarak uktrasonik HC-SR04.

- Hubungan aki dengan motor DC (sebagai putaran roda) ada baiknya terdapat hubungan timbal balik dimana terdapat proses pengisian aki dari tegangan yang dihasilkan oleh motor
DC sehingga tegangan aki dan inputan motor DC cukup stabil.

- Dalam menampilkan informasi pada LCD yang karakternya terbatas harus mampu memberikan informasi hasil pengolahan data yang penting dengan secukupnya, jika ingin menampilkan informasi yang lebih lengkap dapat menggunakan LCD TFT 7".

- Lebih baik membuat simulasi mobil yang mampu berjalan dengan sistem autobrake sehingga alat yang dibuat terlihat realistis.

- Pada sistem autobrake pada mobil ini dalam penerapannya harus memanipulasi mekanik sistem pengereman mobil seperti membuat rongga hidraulis sambungan tersendiri untuk penekanan tuas rem tanpa perlu menginjak pedal rem.

\section{DAFTAR PUSTAKA}

1. Agus Setya Abadi, Delta. 2008. Sensor Ultrasonic Sebagai Alat Navigasi Robot Pemadam Api. Tugas Akhir PSD III Teknik Elektro (tidak diterbitkan). Semarang: Universitas Diponegoro.

2. Bishop, Owen. 2004. Dasar-Dasar Elekrtonika. Jakarta: Penerbit Erlangga.

3. Cahyo Saputro, Adi. 2014. Central Door Lock. Diunduh dari http://otomotifmaju.blogspot.com/2014/08/sent ral-door-lock.html, pada 17 Juni 2015 pukul 21.46 WIB.

4. Chan, Yefri. 2010. Teori Dasar Rem. Buku Panduan Teknik Mesin (tidak diterbitkan). Jakarta Timur: Universitas Darma Persada.

5. Putu Giovani. I. 2014. Merancang Driver Motor DC. Diunduh dari http://www.geyosoft.com/2014/merancangdriver-motor-dc, pada 17 Juni 2015 pukul 08.00 WIB.

6. Prayogo, Rudito. 2012. Pengaturan PWM dengan PLC. Tugas Mata Kuliah Teknik Otomasi (tidak diterbitkan). Malang: Universitas Brawijaya.

7. Roghib, Rokhman, dan M. Qomarruzzaman. 2014. Introduction Arduino Training Kit. Yogyakarta: House Of Technology.

8. Sandi. 2014. Acccumulator Atau Aki. Diunduh dari http://www.sandielektronik.com/2014/03/accu mulator-atau-aki.html, pada 30 Mei 2015 pukul 16.15 WIB.

9. Setyadi, Ary. 2010. Bahasa Indonesia Dalam Karya Ilmiah. Semarang: Fakultas Ilmu Budaya Undip.

10. Sulistyowati, Riny. 2012. Perancangan Prototype System Kontrol Dan Monitoring Pembatas Daya Listrik Berbasis Mikrokontroler. Tugas Akhir Teknik Elektro (tidak diterbitkan). Surabaya: Institut Adhi Tama Surabaya. 
11. Tooley, Mike. 2003. Rangkainan Elektronik Prinsip dan Aplikasi Edisi Kedua. Jakarta:

Penerbit Erlangga. 